\title{
Fish assemblages of shallow intertidal habitats of the Ria Formosa lagoon (South Portugal): influence of habitat and season
}

\author{
Joaquim Ribeiro*, Gonçalo M. Carvalho, Jorge M. S. Gonçalves, Karim Erzini \\ Centro de Ciências do Mar (CCMAR), Faculdade de Ciências do Mar e do Ambiente, Universidade do Algarve, \\ Campus de Gambelas, 8005-139 Faro, Portugal
}

\begin{abstract}
Fish assemblages in seagrass and unvegetated habitats located in shallow intertidal creeks within the saltmarsh area of the Ria Formosa coastal lagoon were sampled with a Riley push net at 3 sites on a monthly basis over a 1 yr period. The objective was to test if both habitats support similar fish assemblages in terms of abundance, diversity, assemblage structure, and size distribution, and to investigate how site and season affect the assemblages. Fish assemblages associated with these habitats were significantly different in terms of diversity, abundance, and assemblage structure. Seagrass supported a larger number of species and greater diversity, while unvegetated habitat supported greater fish numbers but only of a few species. The habitats were dominated by different groups of resident species that were responsible for major differences in fish assemblage structure between habitats. Pomatoschistus microps and young-of-the-year (YOY) Atherina presbyter dominated the unvegetated habitat, while seagrass was dominated by a diverse group of species, in particular syngnathids and small labrids, revealing different habitat preferences. Site and season were determinant factors conditioning the role of habitat in structuring fish assemblages. Distance between habitats, site elevation, and the amount of marsh drained affected fish assemblages in both habitats. Seasonal fluctuations in the presence and abundance of YOY from marine migrant and resident species were responsible for comparable changes in fish assemblage structure in both habitats. Both habitats provide a distinctive nursery area for different species, while common species reveal ontogenic distributional changes between habitats, where smaller fish appear first in unvegetated creeks.
\end{abstract}

KEY WORDS: Fish fauna - Coastal lagoon - Saltmarsh · Intertidal habitats - Seasonal variations · Habitat association $\cdot$ Ria Formosa $\cdot$ South Portugal

- Resale or republication not permitted without written consent of the publisher

\section{INTRODUCTION}

Shallow intertidal habitats within saltmarsh areas can support important communities of fish species, especially the earlier life-history stages (juveniles), including those of many valuable commercial species (Weinstein 1979, Bozeman \& Dean 1980, Kneib 1997). In many parts of the world, saltmarshes have been destroyed or considerably altered by human activities (Kneib 1997, Elliott et al. 2002). Therefore, a better understanding of the functioning of salt- marshes is crucial for protecting these vulnerable habitats.

Most research on saltmarsh fish communities has been carried out in North America (Kneib 1997, Connolly 1999, Cattrijsse \& Hampel 2006), with a more limited number of studies conducted in Australia (e.g. Morton et al. 1987, Connolly et al. 1997, Thomas \& Connolly 2001) and South Africa (e.g. Paterson \& Whitfield 1996, 2000a,b, 2003), and only very few carried out in Europe (e.g. Labourg et al. 1985, Cattrijsse et al. 1994). However, geographic characteris- 
tics of saltmarsh environments are extremely variable, in particular in terms of size, topography, and hydrology, which have relevant implications for fish use of intertidal marsh areas (Kneib 1997, Cattrijsse \& Hampel 2006). U.S. Atlantic marshes are often located below mean high water, and therefore are inundated more frequently and for longer periods than European marshes, which are located mostly above mean high water, being inundated and accessible to fish only during spring high tides. These differences reveal the need for research on a range of saltmarsh types and geographical locations (Paterson $\&$ Whitfield 2003).

In order to assess the fish use of intertidal marsh habitats, several studies have investigated their fish communities, particularly in unvegetated creeks (Cain \& Dean 1976, Shenker \& Dean 1979, Bozeman \& Dean 1980, Rountree \& Able 1992, Paterson \& Whitfield 1996, Paterson \& Whitfield 2003), seagrass beds (Adams 1976, Pollard 1984, Smith et al. 1984, Bell \& Pollard 1989), and vegetated habitats (e.g. Rozas \& Minello 1998, Rozas \& Zimmerman 2000). Other research compared the fish community present in different habitats, mostly between unvegetated creeks and subtidal seagrass (Weinstein \& Brooks 1983, Heck et al. 1989, Ferrell \& Bell 1991, Sogard \& Able 1991, Connolly 1994, Paterson \& Whitfield 2000a). In general, fish assemblages within intertidal marsh areas are formed mainly by estuarine resident and marine migrant species, with an important presence of juvenile fish, revealing that marshes may play a relevant role as nursery grounds. Comparative studies showed that fish communities associated with seagrass and unvegetated creeks within intertidal marsh areas were structurally different, with unvegetated habitats dominated by relatively few species.

In Europe most studies on intertidal marsh habitats concern unvegetated creeks and mud flats (Drake \& Arias 1991a, Cattrijsse et al. 1994, Laffaille et al. 2000, Mathieson et al. 2000, Salgado et al. 2004a, Veiga et al. 2006), with no research on the differences between fish assemblages in intertidal seagrass beds and unvegetated creeks (Cattrijsse \& Hampel 2006). In order to understand the role of these 2 shallow intertidal habitats in the overall ecology of the European saltmarshes, it is crucial to know if they are utilized by different ichthyofaunal communities. We tested the null hypotheses that: (1) there are no differences between the 2 types of habitats with regard to diversity, abundance, assemblage structure, and size distributions; (2) there is no effect of marsh location; and (3) there are no seasonal changes in assemblage.

\section{MATERIALS AND METHODS}

\section{Study area}

This study was carried out in the western part of the Ria Formosa (Ria Faro-Olhão). The Ria Formosa is a large mesotidal coastal lagoon with a semi-diurnal tidal regime and an average spring tidal range of $3.1 \mathrm{~m}$, extending for about $55 \mathrm{~km}$ along the Atlantic south coast of Portugal ( $36^{\circ} 58^{\prime} \mathrm{N}, 8^{\circ} 02^{\prime} \mathrm{W}$ to $37^{\circ} 03^{\prime} \mathrm{N}$, $7^{\circ} 32^{\prime} \mathrm{W}$ ), with a maximal width of $6 \mathrm{~km}$ (Fig. 1). Detailed descriptions of the characteristics of the Ria Formosa are given in Ribeiro et al. $(2006,2008)$.

\section{Sampling design}

Over a 1 yr period, from April 2001 to March 2002, fish fauna were collected from 3 seagrass (Cymodocea nodosa) pools and 3 nearby muddy-sandy bottom unvegetated pools, all located within intertidal creeks of the Ria Formosa marsh area (Fig. 1). The 6 locations are at 3 different marsh sites (A, B, and C), with each containing 1 seagrass and 1 unvegetated pool. Seagrass locations are generally deeper than unvegetated ones, with an average depth in seagrass of 0.70 to $0.80 \mathrm{~m}$ (maximum depth around $1 \mathrm{~m}$, except in site A with $1.20 \mathrm{~m}$ ) and around $0.50 \mathrm{~m}$ in unvegetated creeks (maximum depth around $0.70 \mathrm{~m}$ ). Both habi-

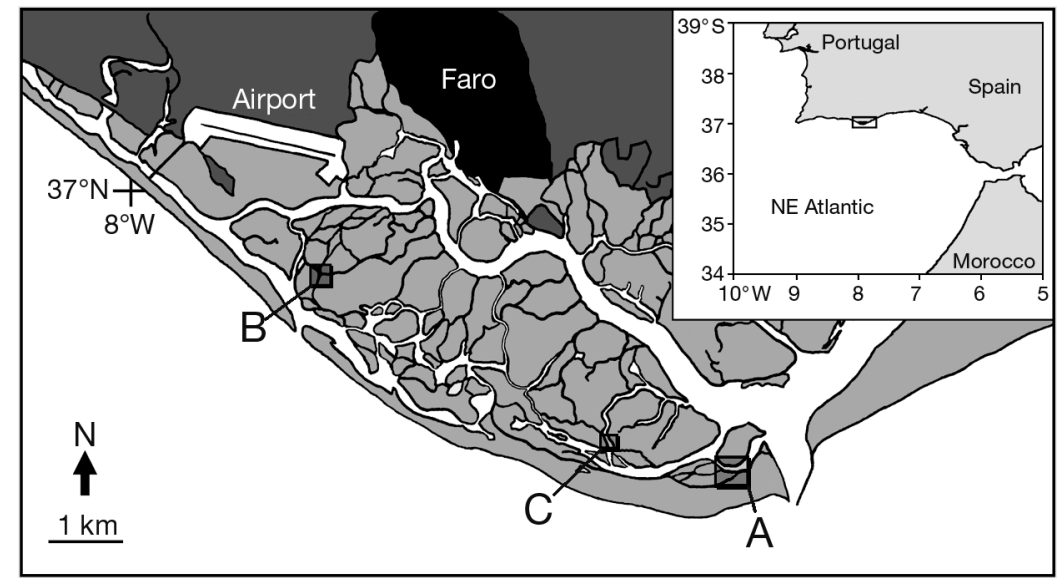

Fig. 1. Western part of the Ria Formosa lagoon (Ria Faro-Olhão) showing the location of the 3 sampling sites 
tats at site $\mathrm{A}$ and the unvegetated habitat at site $\mathrm{B}$ are located approximately $1 \mathrm{~m}$ below high water spring tide level, while the seagrass habitat at site B and both habitats at site $\mathrm{C}$ are located right above the low water spring tide mark. In site $\mathrm{C}$ both habitats are contiguous and connected during the low tide; but in site A both habitats are connected but $20 \mathrm{~m}$ apart; while in site $\mathrm{B}$ the 2 habitats are not connected during low tide and are at a distance of $100 \mathrm{~m}$. The creek at each site drained marsh areas with different sizes, with that at site B draining the largest area and that at site $C$ the smallest area. Each habitat was sampled on a monthly basis using a Riley push net (Holme \& McIntyre 1984) $1.5 \mathrm{~m}$ wide and $0.5 \mathrm{~m}$ high at the mouth, with a stretched mesh size of $2 \mathrm{~mm}$ in the cod end. At each of the 6 locations, sampling took place during low (spring) tides, in day time, and consisted in 3 replicate transects, $30 \mathrm{~m}$ long, covering an area of $45 \mathrm{~m}^{2}$. In order to minimize differences in catch efficiency among samples each replicate took $1 \mathrm{~min}$ $\left(0.5 \mathrm{~m} \mathrm{~s}^{-1}\right)$ (Eleftheriou \& Holme 1984). In the laboratory, all fish were identified to species, counted, and measured to the nearest $\mathrm{mm}$.

\section{Data analysis}

Shannon-Wiener diversity index $\left(H^{\prime}\right)$ (Shannon \& Wiener 1949) was calculated. Three factors were considered: site (A, B, and C); habitat (seagrass and unvegetated); and season (spring, summer, autumn, and winter). A 3-way factorial analysis of variance (ANOVA) was used to test for differences in the number of species, number of fish, and diversity indices, with all factors considered fixed (SAS Institute 1988). When significant main effects were detected in the multifactor ANOVAs, Tukey's honestly significant difference (HSD) test was used to find which means differed. Analysis was performed on the data with the level of significance set to $p \leq 0.01$ to minimize the chances of Type I errors occurring (Underwood 1997). Significant interactions between factors were examined graphically. Paired $t$-tests were used to compare average total length for the most important fish species present in both habitats.

Changes in composition and abundance of fish species (fish assemblage structure) were tested according to the same 3-factor design using the semi-parametric permutational multivariate analysis of variance (PERMANOVA; Anderson 2001, 2005, McArdle \& Anderson 2001). Analysis was conducted using the BrayCurtis measure on $\log _{10}(x+1)$ transformed data, and statistical significance was tested using 9999 permuta- tions of residuals under a reduced model to obtain pvalues (Anderson \& ter Braak 2003). When significant at the 0.05 level, interaction terms were investigated through a posteriori pair-wise comparisons using 9999 random permutations to obtain p-values (Anderson 2005). To visualise significant effects obtained by the previous analysis, principal coordinate analysis (PCo) (unconstrained ordination) and canonical analysis of principal components analysis (constrained ordination) were used (CAP; Anderson \& Robinson 2003, Anderson \& Willis 2003, Anderson 2004). The relative contribution of species to the differences found was assessed using the correlation coefficient resulting between each species and the canonical axis in question, and the correlations of individual species $(|r|>0.40)$ with CAP axes 1 and 2 were plotted.

To compare the fish assemblage functional structure in relation to each factor, species were classified according to an ecological guild classification adapted from Elliott et al. (2007): catadromous (CA), marine stragglers (MS), marine migrants (MM), and lagoon resident (LR) species (adapted from estuarine resident). This classification was chosen because it is a logical extension of previous conceptual models, focusing on a revision and standardization of previous approaches. It also incorporates recent research on the life cycles of fishes in estuaries and takes into account the most recent management strategies for these valuable ecosystems.

\section{RESULTS}

\section{Fish abundance and diversity}

A total of 67666 fish weighing $29066 \mathrm{~g}$ were caught, representing at least 50 species and 17 families (Table 1). Average fish density at site A was 480.1 fish $100 \mathrm{~m}^{-2}$ (37 species), 1498.6 fish $100 \mathrm{~m}^{-2}$ (38 species) at site $B$, and 109.7 fish $100 \mathrm{~m}^{-2}$ (32 species) at site $C$. The seagrass habitat accounted for 36 species and $5.9 \%$ of the fish $\left(70.2\right.$ fish $100 \mathrm{~m}^{-2}$ ), while 41 species and $94.1 \%$ of the fish (1123.2 fish $100 \mathrm{~m}^{-2}$ ) were recorded in the unvegetated habitat. The overall number of species was higher in the unvegetated habitat, but within each site slightly more species were recorded in the seagrass habitat than in the unvegetated habitat (Table 1). Thirteen species were common to both habitats (8 LR and $5 \mathrm{MM}$ ), representing more than $96 \%$ and around $54 \%$ of the fish caught in the unvegetated habitat and seagrass, respectively. Ten species were present only in the seagrass and 14 only in unvegetated habitat (11 MS, 


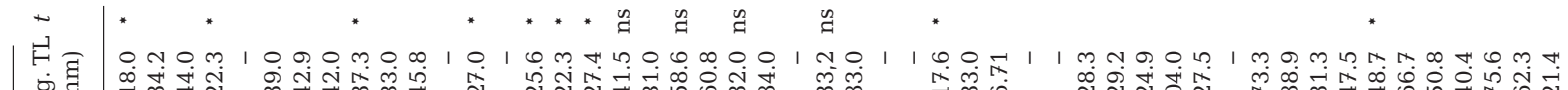

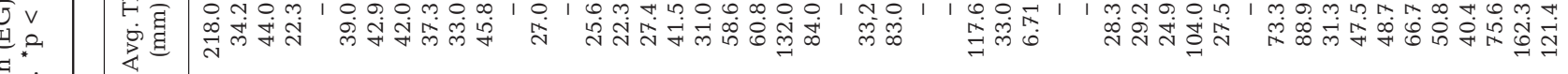

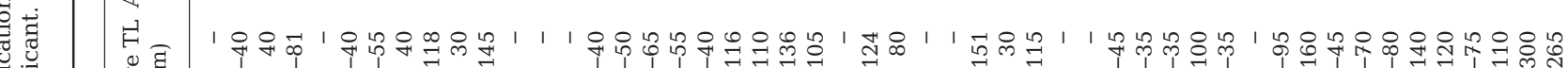

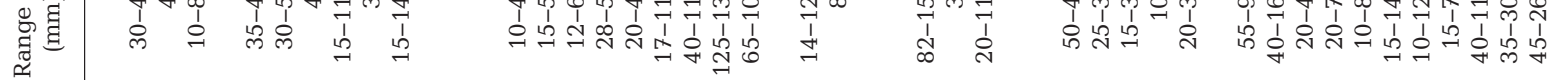

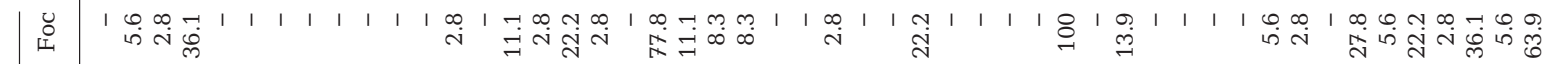

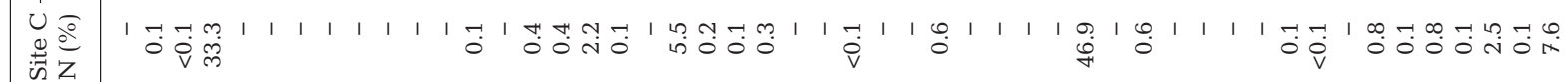

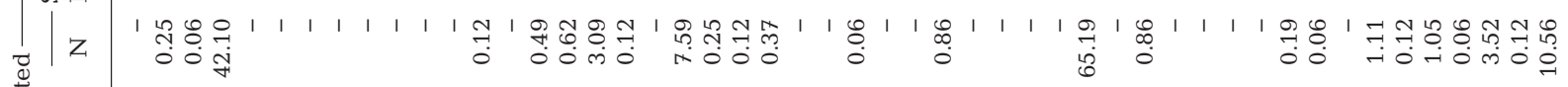
A 1 a $1 \infty$ th $\stackrel{\infty}{i}$, 80

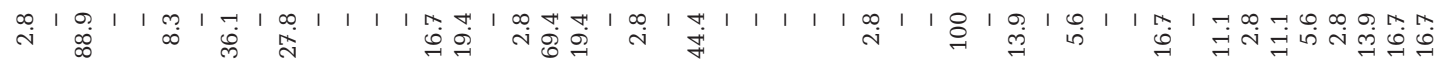

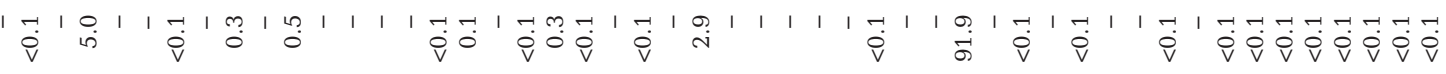

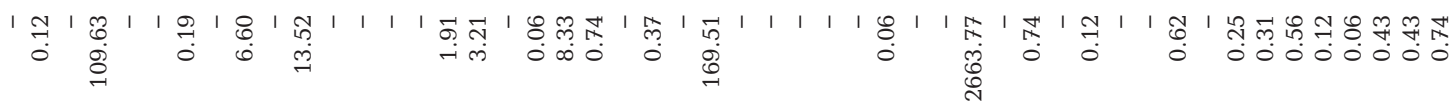

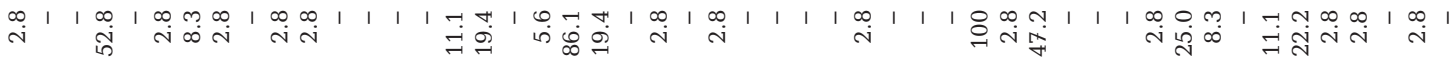

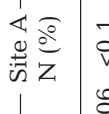

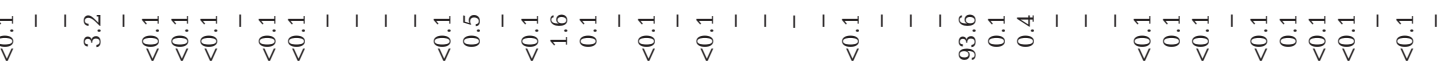
䒴 1 1

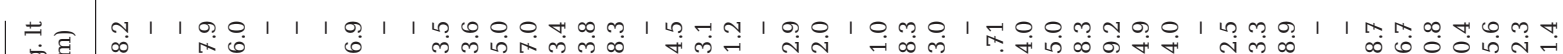

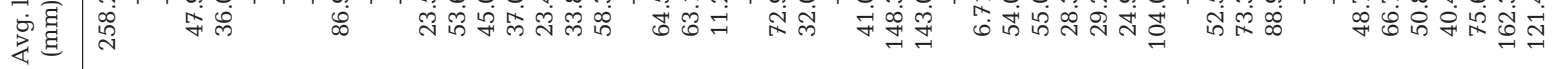

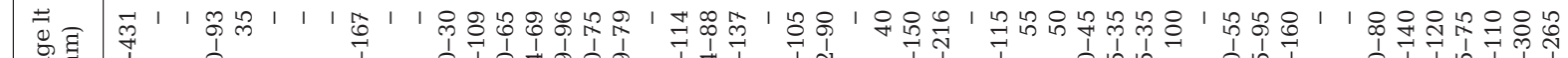
承 O 语兽

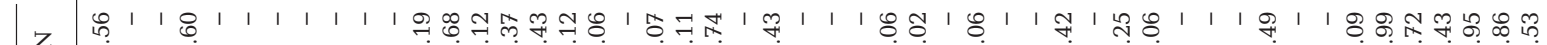
क 率 莺

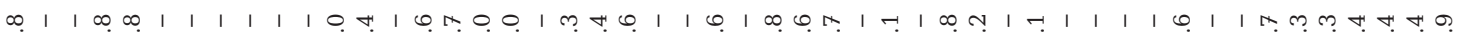
त त्रं -

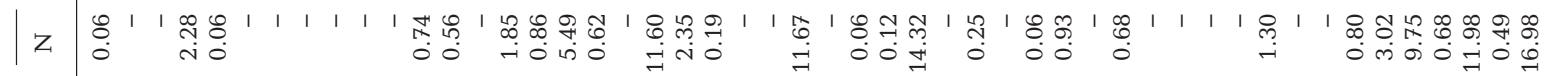

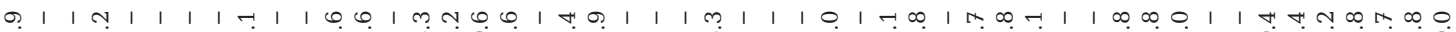

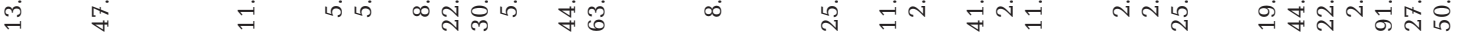
泀后

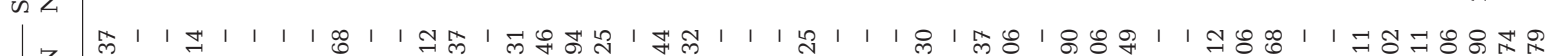
每

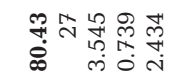
: mo $1 \mathrm{z}$

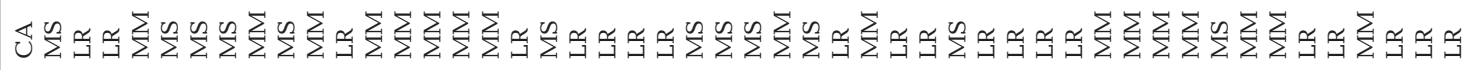


$8 \mathrm{MM}$, and $3 \mathrm{LR})$, representing less than $1 \%$ of the catch in each habitat. Finally, 13 species were present in the 2 habitats but not at all sites, representing approximately $45 \%$ and $3 \%$ of the catch in each habitat.

The size range and the average size of fish caught in the 2 habitats showed both fish assemblages were almost exclusively formed by YOY. However, for the species relatively abundant in the 2 habitats, particularly for MM species, the average sizes were significantly higher in the unvegetated habitat.

The 3-way ANOVA showed that site, habitat and season, were responsible for significant differences in mean number of species (Table 2). Tukey's HSD tests revealed that site $B$ had significantly higher mean numbers of species than site $A$, while seagrass habitats had significantly higher mean numbers of species than unvegetated habitats, and mean number of species was significantly lower in winter than in the other seasons (Fig. 2).

All main effects were responsible for significant differences in mean number of fish, but site-habitat and habitat-season interactions were also significant, indicating that differences among and within each interacting factor should be assessed (Table 2, Fig. 3). For site-habitat interaction, unvegetated habitat had significantly more fish than seagrass within sites $A$ and $B$, where the 2 habitats are separated by more than $50 \mathrm{~m}$, but not for site $\mathrm{C}$ where habitat locations were almost contiguous (Fig. 3b). Within the seagrass habitat there was no significant site variation in fish abundance, while there were significant differences between all sites within the unvegetated habitat, with significantly more fish at site $B$, where the creek drains a much larger inter-

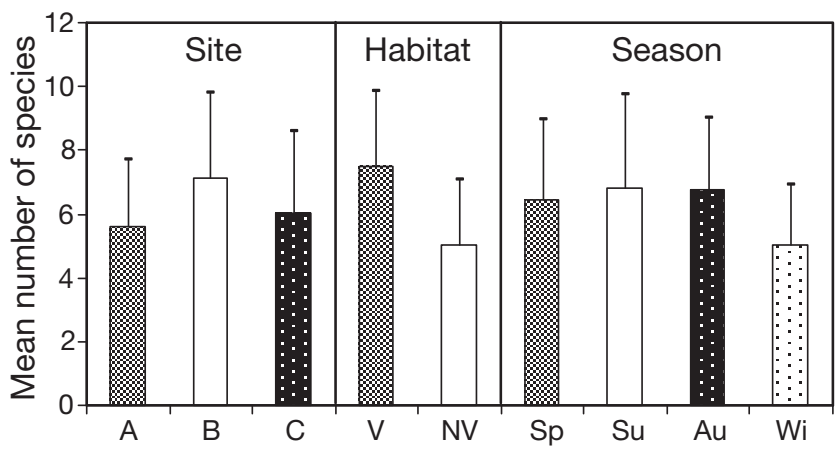

Fig. 2. Mean number of fish species for each factor level. Error bars represent $+1 \mathrm{SE}$
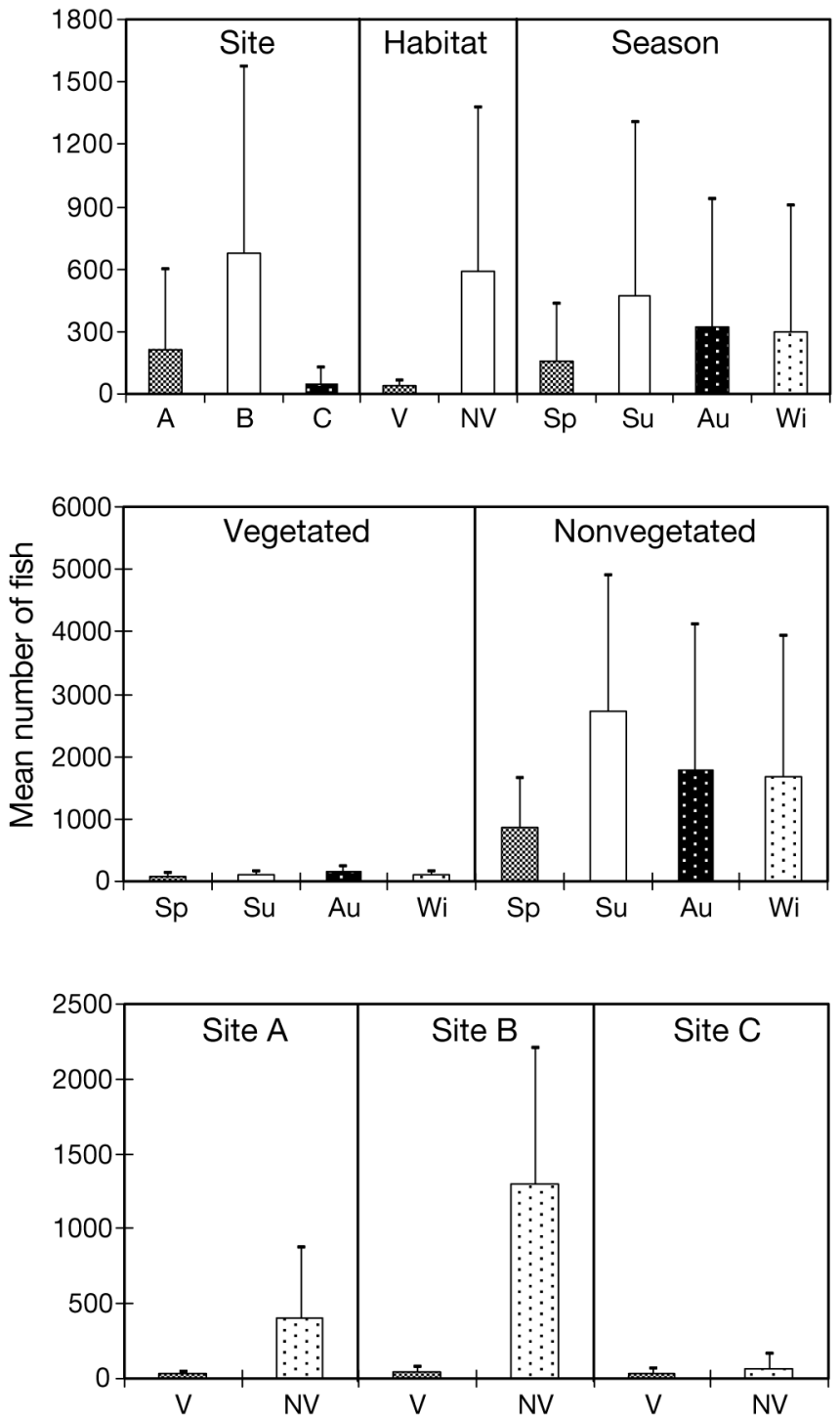

Fig. 3. Mean number of fish for each factor level and for all significant interactions between factor levels. Error bars represent $+1 \mathrm{SE}$ 
tidal marsh area, than in sites $\mathrm{A}$ and $\mathrm{C}$, and with more fish in site $A$ than in site $C$, the creek drains the smallest intertidal marsh area of all 3 unvegetated locations (Fig. 3b). Considering habitat-season interaction, mean number of fish was always significantly higher in the unvegetated habitat than in seagrass independent of the season, and there were significant seasonal differences only for unvegetated habitat, which had more fish in summer than in winter and spring, but no significant differences between other pairs of seasons (Fig. 3c).

Overall, the Shannon-Wiener index was consistently higher in seagrass than in unvegetated locations, independent of site (Table 1). The 3-way ANOVA results for this index showed a significant habitat and site effect (Table 2, Fig. 4), but the sitehabitat interaction was also responsible for significant differences (Table 2). The unvegetated location at site C (located near the subtidal edge) showed significantly higher diversity values than unvegetated locations at sites A and B (located in a more elevated position, further away from subtidal edge), while seagrass showed similar values within sites that were all significantly higher than those observed for unvegetated habitat at all sites (Fig. 4). These results reveal that the habitat effect was significant independent of the site effect, and that unvegetated habitats located at a less elevated position on the marsh, further away

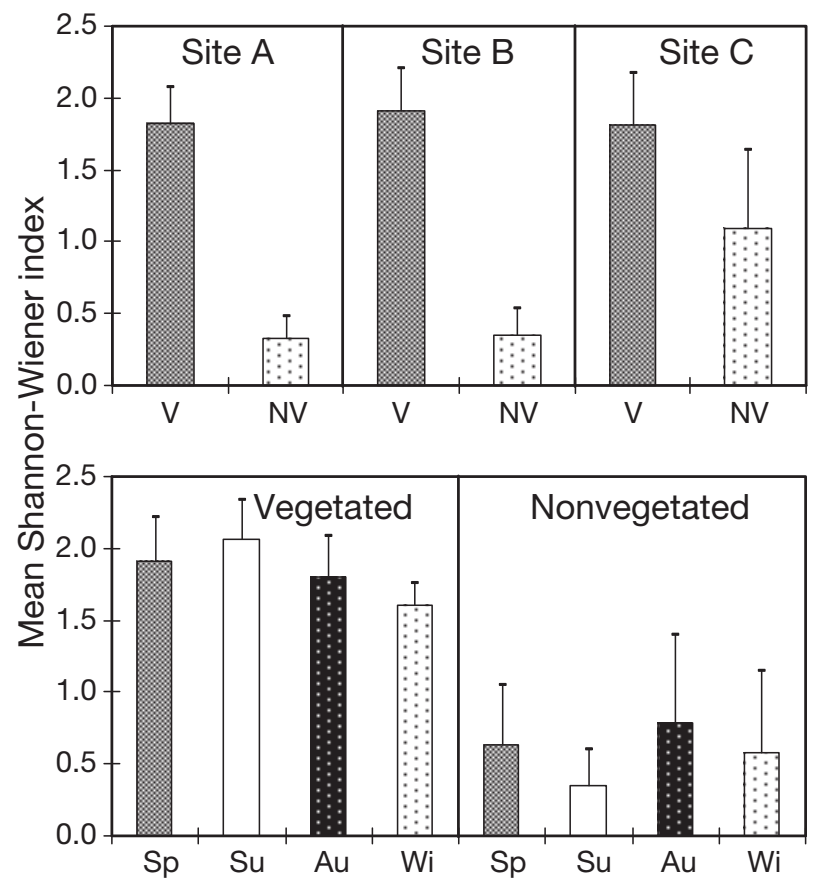

Fig. 4. Mean Shannon-Wiener index $\left(H^{\prime}\right)$ for each factor level and for all significant interactions between factors levels. Error bars represent $+1 \mathrm{SE}$ from subtidal areas, had higher fish diversity. The habitat-season interaction was also significant, with no significant seasonal differences within seagrass habitat, but for the unvegetated habitat, summer values were significantly lower than in autumn and winter, and seagrass always had higher values than unvegetated habitat, independent of season.

\section{Species composition}

Unvegetated habitat locations within sites A and B were clearly dominated year round by the Gobiidae species Pomatoschistus microps, present in all samples and representing more than $90 \%$ of the total catch at each location (Tables $1 \& 3$ ). At site $\mathrm{C}$, this species was again the most abundant and frequent but shared the dominance with the less common Atherina presbyter, which became dominant only in the autumn (68.1\%). This latter species was also the second most abundant in unvegetated habitats at sites $\mathrm{A}$ and $\mathrm{B}$, but with a lower relative importance. A. presbyter was represented mainly by young-ofthe-year (YOY), with approximately $94 \%$ of the fish caught measuring less than $30 \mathrm{~mm}$. Seasonally, $P$. microps clearly attained its greatest abundance in the summer, becoming less abundant in the remaining seasons, while A. presbyter was clearly less abundant in the winter (Table 3). Gobius niger was also an important species in terms of abundance and frequency of occurrence in unvegetated habitats, with similar numbers of fish at the 3 sites. These 3 resident species were present in the 3 unvegetated sampling locations all year round. Chelon labrosus, Dicentrarchus labrax, and Liza aurata, all represented exclusively by YOY, were relatively abundant only at site B, with the first two present most of all during the spring and summer, and the latter almost absent during the summer and more abundant during the autumn. Diplodus vulgaris was also fairly well represented in all unvegetated sites with relatively similar abundance levels, but only between February and July, where all fish caught were YOY. Syngnathus abaster and $S$. typhle were relatively abundant only in site $\mathrm{C}$, during the autumn and winter. The higher values of relative importance for secondary species in site $\mathrm{C}$ were mostly due to the lower abundance of $P$. microps when compared with the other unvegetated locations.

In seagrass habitat locations within sites there was no clear species dominance, and, although the abundance of the most important species was variable from site to site, a group of 9 species represented 


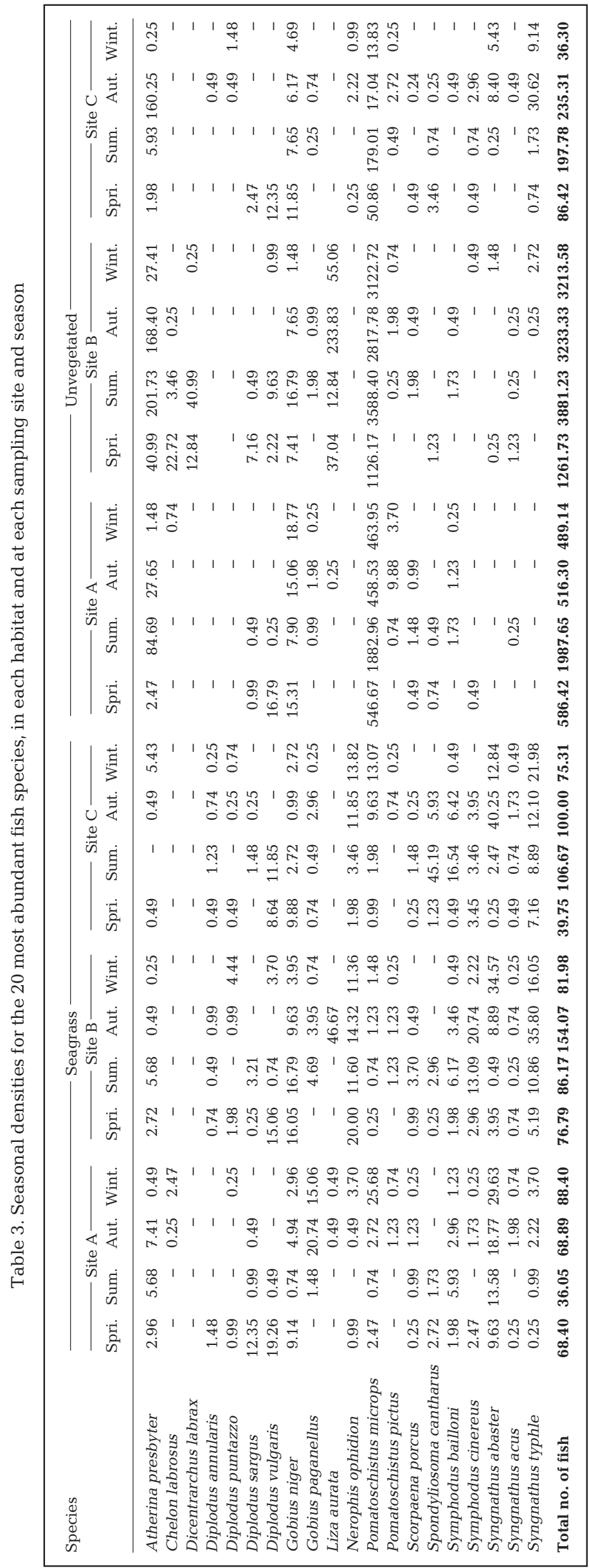

more than $70 \%$ of the catch in numbers at each seagrass location. Species of the Syngnathidae family were generally the most important, representing $38.6 \%$ of the catch in the seagrass, where the most important species were Syngnathus abaster, $S$. typhle, and Nerophis ophidion, which were more abundant in the autumn and winter. Sparidae, represented exclusively by YOY, was the second family in terms of relative importance with $20.7 \%$ of the catch, with Diplodus sargus, D. vulgaris, and $S$. cantharus the most important species, and particularly abundant in spring and/or summer but almost absent in the winter. The Gobiidae family was also important in terms of relative abundance, accounting for more than $10 \%$ of the catch in each seagrass sampling location. Gobius niger, G. paganellus, and Pomatoschistus microps were the most important Gobiidae species, with the first species less abundant in winter, while the last two were more important in autumn and winter. Finally, the Labridae family represented more than $6 \%$ of the catch in each seagrass location, with Symphodus cinereus and Symphodus bailloni the most important numerically and with higher abundances in the summer and autumn. In autumn, YOY of Liza aurata were particularly abundant in the seagrass habitat, but absent from site B except for November.

\section{Fish assemblage structure}

PERMANOVA results showed that there were significant differences in fish assemblage structure due to all 3 main effects, where habitat was the factor responsible for most of the variation within samples, with $F$ values almost $8 \times$ higher than the other factors (Table 4). The unconstrained ordination plot using the fist 2 principal coordinates axes show a clear sep-

Table 4. Results of PERMANOVA testing for differences in fish assemblage structure, in response to habitat, site, season, and interactions effects

\begin{tabular}{|lrrrc|}
\hline Effects & df & \multicolumn{1}{c|}{ MS } & \multicolumn{1}{c|}{$F$} & $\mathrm{p}$ \\
\hline Habitat & 1 & 50905.25 & 79.35 & 0.0001 \\
Site & 2 & 6767.74 & 10.55 & 0.0001 \\
Season & 3 & 7618.02 & 11.87 & 0.0001 \\
Habitat $\times$ Site & 2 & 4405.44 & 6.87 & 0.0001 \\
Habitat $\times$ Season & 3 & 743.34 & 1.159 & 0.3080 \\
Site $\times$ Season & 6 & 1349.95 & 2.10 & 0.0003 \\
Habitat $\times$ Site $\times$ Season & 6 & 837.24 & 1.31 & 0.1197 \\
Residual & 48 & 641.54 & & \\
Total & $\mathbf{7 1}$ & & & \\
\hline
\end{tabular}




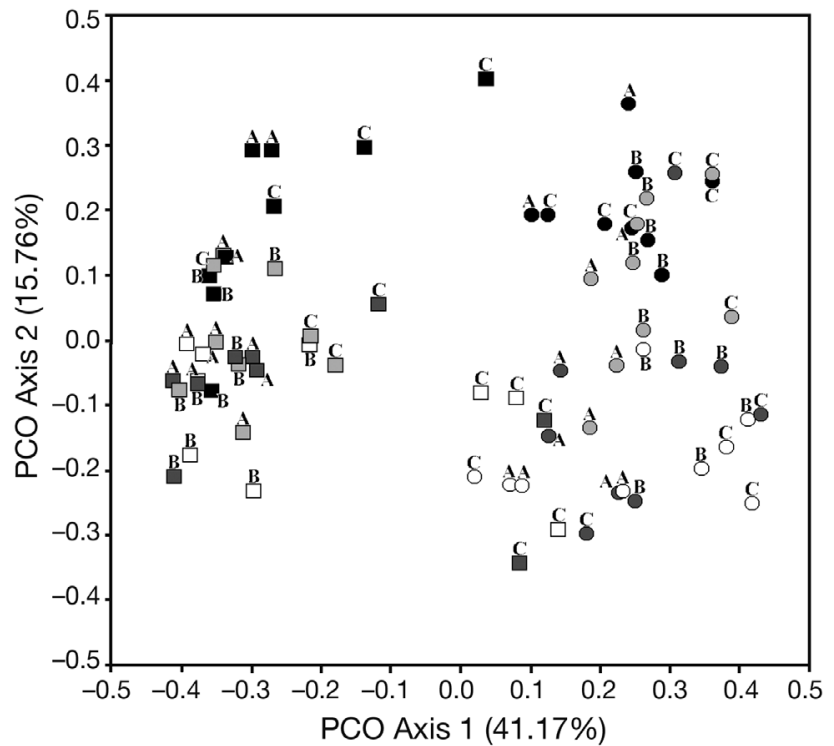

Fig. 5. Unconstrained ordination plot using principal coordinate analysis of the fish species abundance data representing each sample taken in both habitats, at 3 sites and during 12 mo. squares: unvegetated habitat; circles: seagrass; black: spring; light grey: summer; dark grey: autumn; white: winter; letters represent the 3 sites

Table 5. Results of pair-wise comparisons tests for terms for significant interactions found in the PERMANOVA analysis (habitat-site and site-season interactions). ${ }^{*} \mathrm{p}<0.001 ;{ }^{* *} \mathrm{p}<0.01$; ${ }^{* * *} \mathrm{p}<0.05 ;$ ns: not significant

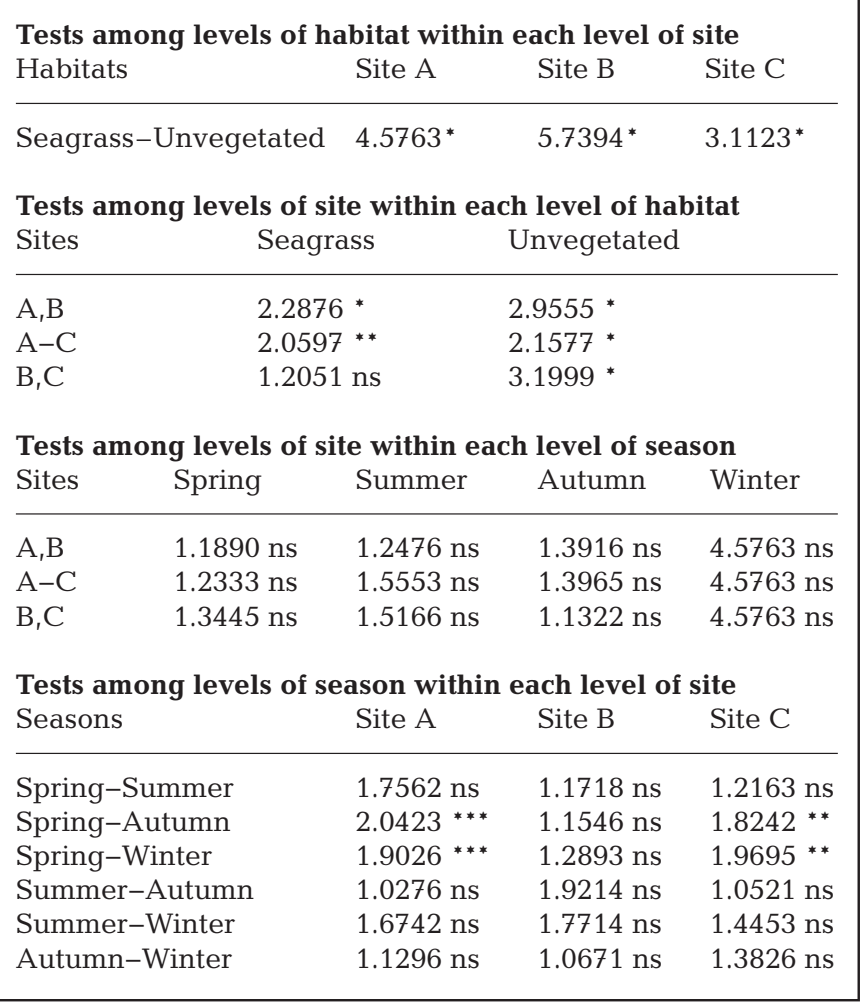

aration of samples by habitat type along the 1st axis, which explained $41.17 \%$ of the variation within samples (Fig. 5). All seagrass samples are distributed on the right side of the plot, while samples collected in unvegetated locations are on left side, with the exception of all winter and 2 autumn samples taken at site $C$, which are mixed with seagrass samples collected in those seasons. However, habitat-site interaction was significant, with pair-wise comparisons showing significant differences in fish assemblage structure among the 2 habitats independent of site levels, and also revealing significant differences among all sites within each habitat, except between sites $\mathrm{B}$ and $\mathrm{C}$ within seagrass (Table 5). These results were perfectly evident in the canonical plot used to discriminate differences among terms of the significant habitat-site interaction (Fig. 6a). Season effect revealed significant differences between all seasons except between summer and autumn, but siteseason interaction was also significant. Pair-wise comparisons showed no significant seasonal changes in fish assemblage structure among sites within each season level, but revealed significant differences be-

tween spring and both autumn and winter, within sites $\mathrm{A}$ and $\mathrm{C}$, and significant differences between summer and winter only at site $\mathrm{C}$, while significant differences between spring and summer were observed only for site A. No significant seasonal differences were observed within site B (Table 5). The canonical plot used to discriminate differences among terms of the significant siteseason interaction shows a clear separation of spring samples from autumn and winter samples at sites A and C. Samples from summer and winter were only slightly separated for site C. Samples from site B were very disperse throughout the plot area, and no clear separation seasonal of samples is evident (Fig. 7a).

The correlation of individual species $(|r|>0.40)$ with CAP axes 1 and 2 regarding habitat-site interaction terms showed that Diplodus annularis, Diplodus puntazzo, Nerophis ophidion, Syngnathus abaster, Symphodus bailloni, Symphodus cinereus, and Symphodus typhle were highly correlated with seagrass samples, with Syngnathus abaster particularly correlated with seagrass samples at site A, and the remaining species particularly correlated with seagrass samples at sites B and C (Fig. 6a). On the other hand, Pomatoschistus microps was highly correlated with unvegetated samples, in particular at sites A and B, and Atherina presbyter, Chelon labrosus, Dicentrarchus labrax, and Liza aurata were only highly 


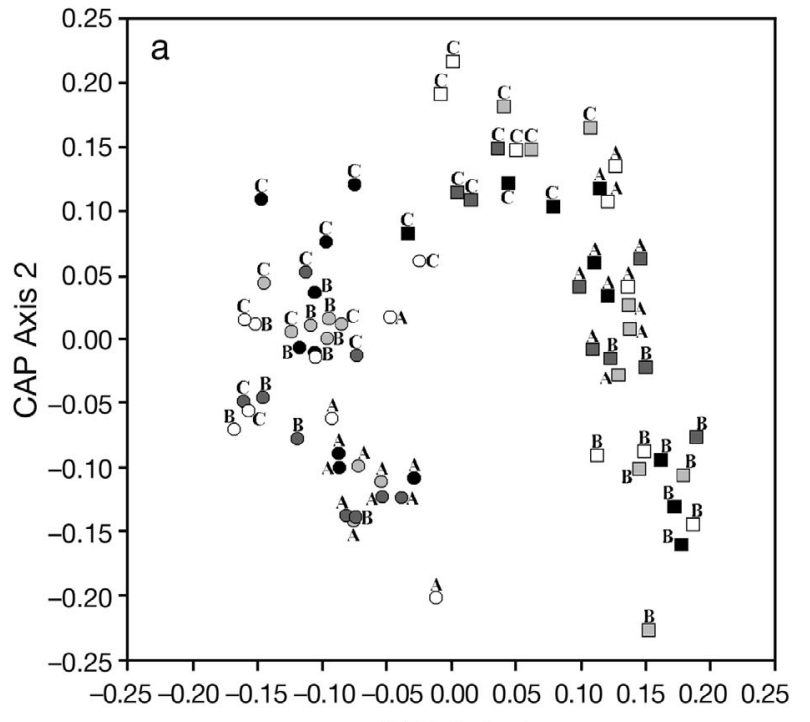

CAP Axis 1

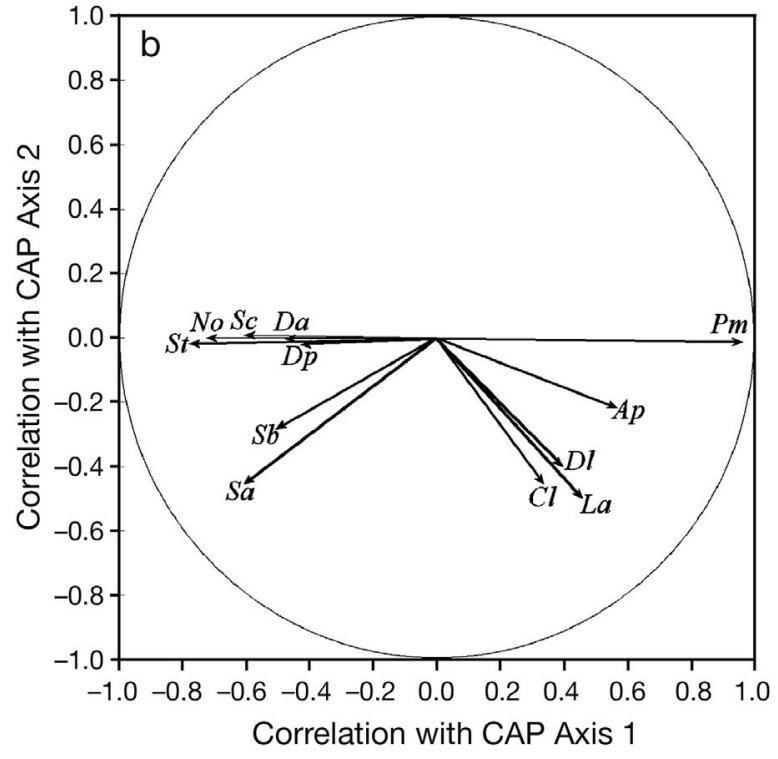

Fig. 6. (a) Constrained ordination plot using CAP analysis of the fish species abundance data, in order to discriminate differences among terms of the significant habitat-site interaction (see Fig. 5 for further explanations). (b) Correlations (|r| $>0.40$ ) of fish species with the 2 previous CAP axes. Ap: Atherina presbyter; Dl: Dicentrarchus labrax; Cl: Chelon labrosus; Da: Diplodus annularis; Dp: Diplodus puntazzo; La: Liza aurata; No: Nerophis ophidian; Pm: Pomatoschistus microps; Sa: Syngnathus abaster; Sb: Symphodus bailloni; Sc: Symphodus cinereus; St: Syngnathus typhle
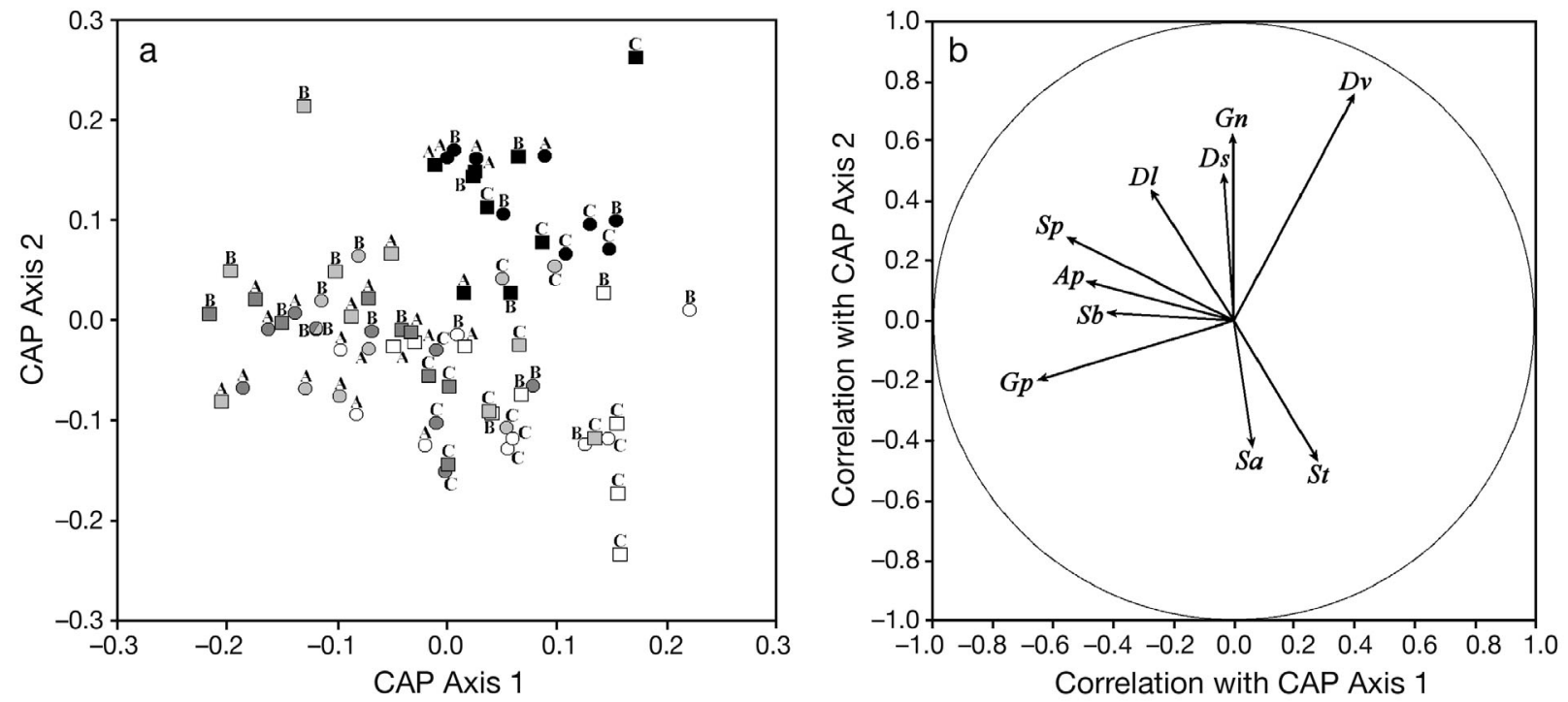

Fig. 7. (a) Constrained ordination plot using CAP analysis of the fish species abundance data, in order to discriminate differences among terms of the significant site-season interaction (see Fig. 5 for further explanations). (b) Correlations (|r| $>0.40$ ) of fish species with the 2 previous CAP axes

correlated with unvegetated samples from site B (Fig. 7b). Considering site-season interaction terms, the correlation of individual species $(|\mathrm{r}|>0.40)$ with CAP axes 1 and 2 revealed that Diplodus vulgaris was highly correlated with spring samples, while Gobius niger and Diplodus sargus were correlated to spring samples mostly at sites A and B. Syngnathus abaster and Syngnathus typhle were highly correlated with autumn and winter samples, in particular at site C. Symphodus bailloni and A. presbyter were correlated with summer and autumn at sites A and B and Gobius paganellus was well correlated only at site A. Scorpaena porcus and Dicentrarchus labrax were well correlated to summer samples at site B. 

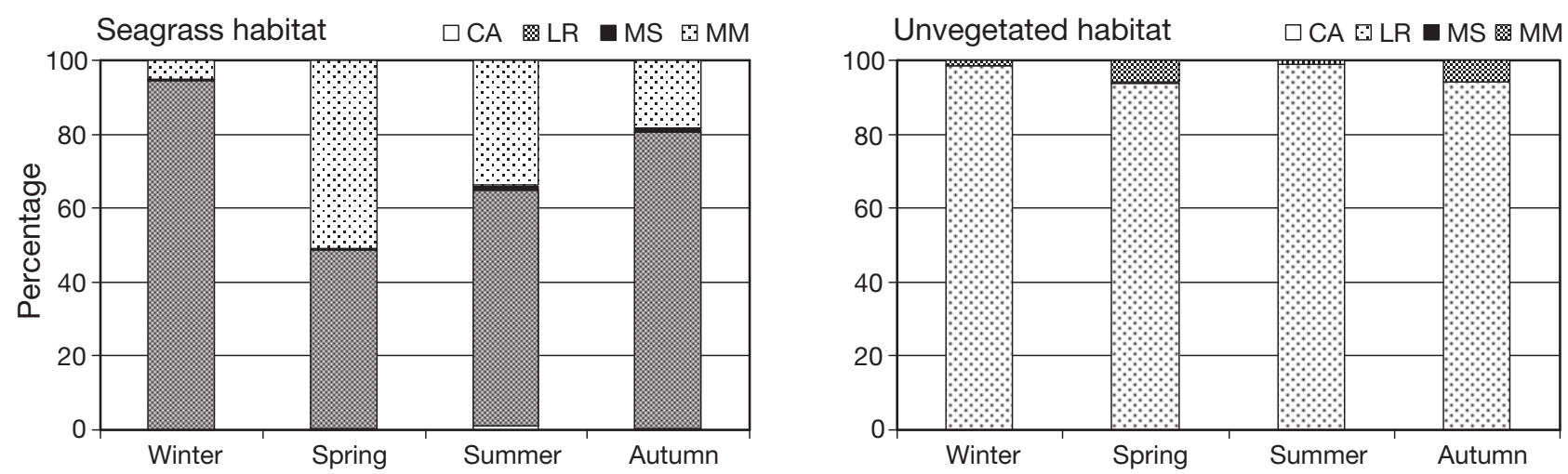

Fig. 8. Percentage of fish number by ecological guild caught in each season over seagrass and unvegetated habitats. CA: catadromous; LR: lagoon residents; MS: marine stragglers; MM: marine migrants

The resident species were always the most important ecological guild present in each sample location, both in terms of number of species and fish abundance (Table 1). This was particularly evident for fish abundance in the unvegetated habitat, where resident species represented more than $95 \%$ of fish caught. MM was the second most abundant group, with $26.5 \%$ in seagrass, but representing only $3.2 \%$ in unvegetated habitat. MS was the least abundant group in both habitats. The 2 habitats showed similar seasonal patterns for ecological guilds in terms of fish abundance, characterized by an increase in relative importance of YOY from MM in the spring, followed by a progressive decrease in summer and autumn, reaching a minimum during the winter, when resident species became clearly dominant in both habitats (Fig. 8). This pattern was more evident in the seagrass habitat, where the MM became dominant in the spring, while in the unvegetated habitat the resident species were clearly dominant all year round.

\section{DISCUSSION}

\section{Habitat differences}

Fish assemblages associated with seagrass and unvegetated habitats, both located within the Ria Formosa intertidal marsh creeks, showed clear differences in terms of fish diversity, abundance, and assemblage structure. Fish diversity in these 2 intertidal habitats was higher over seagrass than in nearby unvegetated areas, as found in subtidal channels of the Ria Formosa (Ribeiro et al. 2006), and also as reported in other similar studies in NE coast of USA (e.g. Weinstein \& Brooks 1983, Sogard \& Able 1991), and in Australia (Ferrell \& Bell 1991, Connolly 1994a), but in contrast to findings of Paterson \& Whit- field (2000a) who reported similar diversities between these 2 habitats in a South African estuary. These authors found similar total number of species in both habitats, very close to those found in the present study, but most of the species found in the unvegetated habitat of Ria Formosa were sporadic, resulting in an average number of species significantly higher in the seagrass. In spite of this, differences in diversity were most of all due to an overwhelming dominance of one single species, Pomatoschistus microps, in the unvegetated habitat, compared to the seagrass habitat where there was no dominance by a particular species, rather than to substantial differences in number of species observed in each habitat. Again, studies from the NE coast of the USA and Australia showed that intertidal unvegetated marsh creek habitats support high fish densities, but only from few species (e.g. Cain \& Dean 1976, Kneib 1987), and in general higher than nearby seagrass (Weinstein \& Brooks 1983, Ferrell \& Bell 1991, Sogard \& Able 1991). In contrast, some studies from South African estuaries (Branch \& Grindley 1979, Beckley 1983, Paterson \& Whitfield 2000a) reported higher fish densities in seagrass than in unvegetated marsh creeks. Studies in European estuarine saltmarshes found, like in the present study, that $P$. microps was the most dominant fish species in the intertidal marsh areas, in particular in unvegetated marsh creeks (Drake \& Arias 1991a,b, Cattrijsse et al. 1994, Hampel et al. 2003, Salgado et al. 2004a,b, Cattrijsse \& Hampel 2006, Veiga et al. 2006). The huge abundance of P. microps, and to a lesser extent the abundant presence of Atherina presbyter YOY, were clearly responsible for the much greater fish densities in the unvegetated habitats, except for site C where differences in abundance between habitats were not significant. These abundances are related to the capacity of these species to distribute and 
move along the tide edge, allowing them to use the intertidal marsh area during the high tide, and to withdraw during the ebb tide, returning to the very shallow intertidal creeks and pools where they remain concentrated during the low tide (Cattrijsse et al. 1994, Kneib 1997). The use of the intertidal marsh surface allows them to find shelter, avoid predation, and feed in the productive intertidal saltmarsh foraging grounds that are only available for short periods twice a day during the high tide in the European saltmarshes (Hampel \& Cattrijsse 2004).

Although the abundant presence of Atherinidae species (e.g. Atherina boyeri and A. presbyter) in south European estuaries and coastal areas (Atlantic and Mediterranean) is well known (Labourg et al. 1985, Bouchereau et al. 2000, Guidetti \& Bessotti 2000), the abundant presence of YOY from Atherinidae family in intertidal areas of European saltmarshes is not well documented. However, in shallow littoral zones along the U.S. coast, species of the Atherinidae family (e.g. Menidia menidia) use the tidal edge in order to gain access to intertidal marsh habitats (Allen 1982, Rountree \& Able 1992), and in particular their larvae and juveniles use these habitats during the first period of their life history (Middaugh 1981, Middaugh \& Takita 1983, Conover \& Kynard 1984). The dynamic pattern of distribution along the tide edge could explain why Pomatoschistus microps and A. presbyter YOY were so much more abundant at low tide in the unvegetated creek than in seagrass, since the unvegetated habitats locations were less deep, and therefore closer to the tidal edge.

Intertidal marsh habitats ichthyofaunal assemblages were characterized by the presence of $\mathrm{MM}$ and LR, with LR dominating both assemblages, as reported in several studies (Rakocinski et al. 1992, Kneib \& Wagner 1994, Thomas \& Connolly 2001), but in contrast to Paterson \& Whitfield (2000a) who reported the dominance of MM in unvegetated creek marsh habitats. However, fish assemblage structure associated with shallow intertidal seagrass differed from those found over unvegetated habitats, as reported in similar comparative studies (Weinstein \& Brooks 1983, Heck et al. 1989, Ferrell \& Bell 1991, Sogard \& Able 1991, Connolly 1994, Paterson \& Whitfield 2000a). Distinct fish assemblage structure was mostly due to differences in abundance of common species among habitats as found in the NE coast of the United States (Weinstein \& Brooks 1983, Sogard \& Able 1991), rather than species specifically present in one habitat, as found in a South African estuary (Paterson \& Whitfield 2000a) and in the SW coast of Australia (Ferrell \& Bell 1991, Connolly 1994). Nevertheless, the most abundant species in each habitat were LR species predominantly represented in one single habitat, reflecting a clear habitat preference. Pomatoschistus microps and YOY of Atherina presbyter were by far the predominant species in the unvegetated habitat, while the syngnathids Nerophis ophidion, Syngnathus abaster, Syngnathus typhle, and small labrids Symphodus bailloni and Symphodus cinereus were predominant in the seagrass, and poorly represented in unvegetated habitats (except in site $\mathrm{C}$, during autumn and winter). The close association of syngnathids, in particular the Syngnathus genera, to seagrass habitats in coastal and estuarine environments is well known in Atlantic-Mediterranean and Indo-Pacific regions, where they are among the most frequent and abundant species in these habitats (Pollard 1984, Howard \& Koehn 1985, Rossi 1986, Franzoi et al. 1989). Differences in fish assemblage structure, associated with habitat preferences from LR species, reveal their importance as a structuring component of the fish assemblage in the intertidal marsh habitats in the Ria Formosa, and also indicate their potential importance in the functioning of the marsh ecosystem as a vector in the transfer of intertidal production to subtidal areas (Kneib \& Wagner 1994, Kneib 1997). Although some YOY from MM species did not show any clear habitat preference, in particular Diplodus vulgaris and Diplodus sargus, others showed preference for seagrass habitats, such as Diplodus annularis, Diplodus puntazzo, and Spondyliosoma cantharus, while others such as Chelon labrosus, Dicentrarchus labrax, and Liza aurata preferred unvegetated habitats. These last 3 species were present almost exclusively in the unvegetated location at site B, probably because recruitment into the intertidal areas is likely a random process for most MM species, but their absence or lower abundance in the nearby seagrass habitat should indicate a habitat selection and preference. The presence of YOY of Dicentrarchus labrax and Mugilidae species (e.g. C. labrosus and L. aurata), as well as their foraging activities in the unvegetated intertidal marsh creeks has been reported in several west Atlantic European saltmarshes (Kelley 1988, Cattrijsse et al. 1994, Laffaille et al. 2000, 2002, Hampel et al. 2005, Veiga et al. 2006), and in Mediterranean coastal lagoons (Labourg et al. 1985, Bouchereau et al. 2000). The presence of mugilid YOY in intertidal creeks is also common in other parts of the world (Shenker \& Dean 1979, Bozeman \& Dean 1980, Paterson \& Whitfield 2000b, Thomas \& Connolly 2001). 
Habitat preferences could be the result of differences in species dietary regimes (Burchmore et al. 1984), since the 2 habitats provide distinct and abundant food resources (Whitfield 1988), but also a consequence of different predatory avoidance strategies (Bell \& Pollard 1989), where seagrass, a structurally more complex habitat (Orth et al. 1984), could provide an opportunity to employ cryptic mechanisms to blend into background structure (e.g. labrids and syngnathids), while the unvegetated environment is more suitable for schooling (e.g. Atherina presbyter and Liza aurata) or camouflage against the sediment (e.g. Pomatoschistus microps), as observed by Paterson \& Whitfield (2000a). Diet studies of 0-group sea bass in the Tagus estuary (Cabral \& Costa 2001) and the Po River delta (Ferrari \& Chieregato 1981) have shown that smaller sized stages $(<30 \mathrm{~mm}$ standard length) are predominantly planktophagous, while larger juveniles feed preferentially on macroplankton (Decapoda, Mysidacea, Isopoda, and fish larvae), that may be more abundant and easier to capture in the structurally less complex, unvegetated habitat. The preference of syngnathids and labrids in seagrass habitats in the Ria Formosa lagoon was also reported for subtidal areas within the main channels (Erzini et al. 2002, Ribeiro et al. 2006).

\section{Site differences}

Habitat has a major role in structuring the fish assemblages present in the Ria Formosa intertidal marsh creeks, but significant habitat-site interactions showed that site was a determinant factor conditioning the habitat role. Site characteristics such as site elevation, distance to the marsh, water depth, and submergence duration have a relevant effect on the fish assemblages present in the intertidal marsh area (Kneib \& Wagner 1994, McIvor \& Rozas 1996, Kneib 1997, Thomas \& Connolly 2001). Differences in fish assemblages between habitats, although significant at all sites, were less evident at site $\mathrm{C}$, where both habitats were located near the subtidal edge, and only a few $m$ distant from each other. Several studies have shown that fish assemblages associated with different habitats located within subtidal areas tend to be more similar than those in intertidal areas, since subtidal areas are more accessible to all fish species (Kneib \& Wagner 1994, Kneib 1997). On the other hand, Ferrell \& Bell (1991) showed that differences in fish assemblages between unvegetated and seagrass habitats were negatively related to distance between habitats.
In seagrass, differences among sites were not significant in terms of fish diversity and abundance, but in terms of assemblage structure there were significant differences between sites B and C, both located near the subtidal edge, and site $A$, located in a more elevated intertidal position. These differences in the fish assemblage structure were mainly related to changes in abundance of syngnathids and labrids, with the small syngnathid, Syngnathus abaster, more abundant in a more elevated intertidal area of the marsh, while larger syngnathids such as Nerophis ophidion and Syngnathus typhle, and the labrid Symphodus cinereus, are more abundant in the subtidal areas. Malavasi et al. (2007) reported a certain degree of habitat segregation between these 3 syngnathids in a Mediterranean coastal lagoon, probably related with a combination of several factors, such as structural complexity, predation, and competition.

Within the unvegetated habitat there were significant differences between sites in terms of fish abundance, fish diversity, and assemblage structure. Differences in fish diversity, although not tested, were negatively related to site elevation, where sites located in more elevated locations within the marsh (sites A and B), and consequently further way from subtidal areas, presented a lower diversity than the site located closer to the subtidal edge (site C). Similar results were reported by Thomas \& Connolly (2001) in Western Australia, with fish diversity decreasing with distance from the marsh. In addition to site elevation, it was possible to positively relate fish abundance with the amount of marsh area drained through each unvegetated creek, since fish abundance was higher, in particular for Pomatoschistus microps and Atherina presbyter, in sites that drained larger saltmarsh areas. This supports the idea that these species follow the tide edge, becoming trapped within the marsh area and concentrated in very shallow intertidal pools formed along tidal creeks at low tide (Crabtree \& Dean 1982, Kneib 1997).

\section{Seasonal differences and nursery value}

Annual fluctuations in the presence and abundance of YOY from MM and LR were responsible for comparable seasonal changes in fish assemblage structure in both habitats. The abundant presence of YOY in the spring, in particular of MM species, represented a clear seasonal discontinuity in the structures of the fish assemblages of the 2 habitats. During the summer and autumn, YOY abundance progressively decreases, becoming almost absent in winter. 
This seasonal pattern is related with the recruitment of early life history stages of MM species, which enter the lagoon in late winter and spring, with most returning to the adjacent coastal waters as juveniles or maturing adults in late autumn and winter (Monteiro et al. 1987, Erzini et al. 2002, Ribeiro et al. 2006). The recruitment of MM species during the spring and summer is consistent with the late winter and spring spawning season of most of these species (Gonçalves \& Erzini 2000a,b). The decline in numbers in autumn and winter, both in intertidal and subtidal areas is associated with migrations out of the lagoon to the adjacent coastal waters (Monteiro et al. 1987, Erzini et al. 2002, Ribeiro et al. 2006).

Seasonal fluctuations in the dominant LR species were also responsible for changes in fish assemblages, in particular in the unvegetated habitat, where Pomatoschistus microps abundance is higher in the summer and lower in spring, superimposing lower and higher diversity index values in summer and spring, respectively. Atherina presbyter was also abundant in the unvegetated habitat from summer to autumn, when the recruits settle in the intertidal marsh area. In contrast, the syngnthids, the most abundant group of resident species present in vegetated habitats, are more abundant in the autumn and winter when the YOY recruit after the reproduction season during spring and summer.

Both seagrass and unvegetated shallow habitats within the Ria Formosa intertidal saltmarsh creeks sustain significant populations of juvenile fish of LR and MM species, some of them commercially important. A number of studies carried out in different parts of the world showed that these 2 habitats are important nursery habitats (Cain \& Dean 1976, Weinstein 1979, Bozeman \& Dean 1980, Weinstein et al. 1980, Rountree \& Able 1992). The contrasting fish community structure within the 2 habitats indicates that each provides a distinctive nursery area for different fish species. Unvegetated intertidal creeks were an important habitat for early life stages from LR species Atherina presbyter, and for MM species such as Chelon labrosus, Dicentrarchus labrax, and Liza aurata, while seagrass has a similar role for small labrids and plays an important role in the settlement of juvenile syngnthids. The average length for most important MM species and for the LR species $A$. presbyter was significantly different in both habitats. In the unvegetated habitat only very early juvenile stages were present, while more advanced juvenile stages were dominant in the seagrass, suggesting an ontogenetic change in habitat for these species.
Acknowledgements. This research was funded in part by the European Commission (EC-DG XIV/C1; Study project no. 99/061) and was also sponsored by the Fundação para Ciência e Tecnologia through a PhD grant awarded to J.R. (grant reference: SFRH/BD/6812/2001, Portuguese Ministry of Science and Technology). The authors thank all the colleagues and volunteers who assisted with the field sampling and laboratory work and also the Parque Natural da Ria Formosa.

\section{LITERATURE CITED}

Adams SM (1976) The ecology of eelgrass, Zostera marina (L.), fish communities. I. Structural analysis. J Exp Mar Biol Ecol 22:269-291

Allen LG (1982) Seasonal abundance, composition and productivity of the littoral fish assemblage in upper Newport Bay, California. Fish Bull 80:769-790

Anderson MJ (2001) A new method for non-parametric multivariate analysis of variance. Austral Ecol 26:32-46

Anderson MJ (2004) CAP: a FORTRAN computer program for canonical analysis of principal coordinates. Department of Statistics, University of Auckland, Auckland

Anderson MJ (2005) PERMANOVA: a FORTRAN computer program for permutational multivariate analysis of variance. Department of Statistics, University of Auckland, Auckland

Anderson MJ, Robinson J (2003) Generalised discriminant analysis based on distances. Austral NZ J Stat 45: 301-318

Anderson MJ, ter Braak CJF (2003) Permutation tests for multi-factorial analysis of variance. J Statist Comput Simulation 73:85-113

Anderson MJ, Willis TJ (2003) Canonical analysis of principal coordinates: a useful method of constrained ordination for ecology. Ecology 84:511-525

Beckley LE (1983) The ichthyofauna associated with Zostera capensis Setchell in the Swartkops Estuary, South Africa. S Afr J Zool 18:15-24

Bell JD, Pollard DA (1989) Ecology of fish assemblages and fisheries associated with seagrasses. In: Larkum AWD, McComb AJ, Shepard SA (eds) Biology of seagrasses: a treatise on the biology of seagrasses with special reference to the Australian region. Elsevier, Amsterdam, p 565-609

Bouchereau JL, Guelorget O, Vergne Y, Perthuisot JP (2000) L'Ichtyofaune dans l'organisation biologique d'un systeme paralique de type lagunaire: le complexe des etangs du Prevost et de l'Arnel (Languedoc, France). Vie Milieu 50:19-27

Bozeman EL, Dean JM (1980) The abundance of estuarine larval and juvenile fish in a South Carolina intertidal creek. Estuaries 3:89-97

Branch GM, Grindley JR (1979) Ecology of southern African estuaries. XI. Mngazana: a mangrove estuary in the Transkei. S Afr J Zool 14:149-170

Burchmore JJ, Pollard DA, Bell JD (1984) Community structure and trophic relationships of the fish fauna of an estuarine Posidonia australis seagrass habitat in Port Hacking, New South Wales. Aquat Bot 18:71-87

Cabral H, Costa MJ (2001) Abundance, feeding ecology and growth of 0-group sea bass, Dicentrarchus labrax, within the nursery areas of the Tagus estuary. J Mar Biol Assoc UK 81:679-682 
Cain RL, Dean JM (1976) Annual occurrence, abundance and diversity of fish in a South Carolina intertidal creek. Mar Biol 36:369-379

Cattrijsse A, Hampel H (2006) European intertidal marshes: a review of their habitat functioning and value for aquatic organisms. Mar Ecol Prog Ser 324:293-307

Cattrijsse A, Makwaia ES, Dankwa HR, Hamerlynck O, Hemminga MA (1994) Nekton communities of an intertidal creek of a European estuarine brackish marsh. Mar Ecol Prog Ser 109:195-208

Connolly RM (1994) A comparison of fish assemblages from seagrass and unvegetated areas of a southern Australian estuary. Aust J Mar Freshwater Res 45:1033-1044

Connolly RM (1999) Saltmarsh as habitat for fish and nektonic crustaceans: challenges in sampling designs and methods. Aust J Ecol 24:422-430

> Connolly RM, Dalton A, Bass DA (1997) Fish use of an inundated saltmarsh flat in a temperate Australian estuary. Aust J Ecol 22:222-226

> Conover DO, Kynard BE (1984) Field and laboratory observations of spawning periodicity and behaviour of a northern population of Atlantic silverside, Menidia menidia (Pisces: Atherinidae). Environ Biol Fishes 11:161-171

Crabtree RE, Dean JM (1982) The structure of two South Carolina estuarine tide pool fish assemblage. Estuaries 5:2-9

> Drake P, Arias AM (1991a) Composition and seasonal fluctuations of the ichthyoplankton community in a shallow tidal channel of Cadiz Bay (S.W. Spain). J Fish Biol 39: 245-263

Drake P, Arias AM (1991b) Ichthyoplankton of a shallow coastal inlet in south-west Spain: factors contributing to colonization and retention. Estuar Coast Shelf Sci 32: 347-364

Eleftheriou A, Holme NA (1984) Macrofaunal techniques. In: Holme NA, McIntyre AD (eds) Methods for the study of marine benthos. Blackwell Scientific Publications, Oxford, p 140-216

Elliott M, Hemingway KL, Costello MJ, Duhamel S and others (2002) Links between fish and other trophic levels. In: Elliott M, Hemingway K (eds) Fishes in estuaries. Blackwell Science, Oxford, p 124-217

Elliott M, Whitfield AK, Potter IC, Blaber SJM, Cyryus DP, Nordlie FG, Harrison TD (2007) The guild approach to categorizing estuarine fish assemblages in estuaries: a global review. Fish Fish 8:241-268

Erzini K, Bentes L, Coelho R, Correia C, Lino PG, Monteiro P, Ribeiro J, Gonçalves JMS (2002) Recruitment of sea breams (Sparidae) and other commercially important species in the Algarve (southern Portugal). Final Report, DG XIV/C/1, Ref 99/061, University of Algarve, Faro

Ferrell DJ, Bell JD (1991) Differences among assemblages of fish associated with Zostera capricorni and bare sand over a large spatial scale. Mar Ecol Prog Ser 72:15-24

> Ferrari I, Chieregato AR (1981) Feeding habits of juvenile stages of Sparus auratus L., Dicentrarchus labrax L. and Mugilidae in a brackish embayment of the Po River delta. Aquaculture 25:243-257

Franzoi P, Trisolini R, Carrieri A, Rossi R (1989) Caratteristiche ecologiche del popolamento ittico ripario della Sacca di Scadovari (Delta del Po). Nova Thalassia 10: 399-405

Gonçalves JMS, Erzini K (2000a) The reproductive biology of Spondyliosoma cantharus (L) from the SW coast of Portugal. Sci Mar 64:403-411
Gonçalves JMS, Erzini K (2000b) The reproductive biology of the two banded sea bream (Diplodus vulgaris) from the southwest coast of Portugal. J Appl Ichthyology 16: $110-116$

Guidetti P, Bessotti S (2000) Fish fauna of a mixed meadow composed by the seagrasses Cymodocea nodosa and Zostera noltii in the western Mediterranean. Oceanol Acta 23:759-770

Hampel H, Cattrijsse A (2004) Temporal variation in feeding rhythms in a tidal marsh population of the common goby Pomatoschistus microps (Kroyer, 1838). Aquat Sci 66: 315-326

> Hampel H, Cattrijsse A, Vincx M (2003) Effect of tidal, diel and lunar cycle to the nekton communities in a salt marsh of the Westerschelde. Estuar Coast Shelf Sci 56: 795-805

> Hampel H, Cattrijsse A, Elliott M (2005) Feeding habit of young predator fishes in marsh creeks situated along the salinity gradient of the Westerschelde estuary, The Netherlands. Helgol Mar Res 59:151-162

Heck KL Jr., Able KW, Fahay MP, Roman CT (1989) Fishes and decapod crustaceans of Cape Cod eelgrass meadows: species composition seasonal abundance and comparison with unvegetated substrates. Estuaries 12:59-65

Holme NA, McIntyre AD (1984) Methods for the study of marine benthos. Blackwell Scientific Publishers, Oxford

Howard RK, Koehn JD (1985) Population dynamics and feeding ecology of pipefish (Syngnathidae) associated with eelgrass beds of Western Port, Victoria. Aust J Mar Freshwater Res 36:361-370

Kelley DF (1988) The importance of estuaries for seabass, Dicentrarchus labrax (L.). J Fish Biol 33:25-33

> Kneib RT (1987) Predation risk and use of intertidal habitats by young fishes and shrimp. Ecology 68:379-386

Kneib RT (1997) The role of tidal marshes in the ecology of estuarine nekton. Oceanogr Mar Biol Annu Rev 35: 163-220

> Kneib RT, Wagner SL (1994) Nekton use of vegetated habitats at different stages of tidal inundation. Mar Ecol Prog Ser 106:227-238

Labourg PJ, Clus C, Lasserre G (1985) Preliminary results on the distribution of juvenile fish assemblages occupying a tidal marsh in Arcachon Bay (France). Oceanol Acta 8: $331-341$

> Laffaille P, Feunteun E, Lefeuvre JC (2000) Composition of fish communities in a European macrotidal salt marsh (the Mont Saint-Michel Bay, France). Estuar Coast Shelf Sci 51:429-438

Laffaille P, Feunteun E, Lefebvre C, Radureau A, Sagan G, Lefeuvre JC (2002) Can thin-lipped mullet directly exploit the primary and detritic production of European macrotidal salt marshes? Estuar Coast Shelf Sci 54: 729-736

Malavasi S, Franco A, Riccato F, Valerio C, Torricelli P, Franzoi P (2007) Habitat selection and spatial segregation in three pipefish species. Estuar Coast Shelf Sci 75: 143-150

> Mathieson S, Cattrijsse A, Costa MJ, Drake P, Elliott M, Gardner J, Marchand J (2000) Fish assemblages of European tidal marshes: a comparison based on species, families and functional guilds. Mar Ecol Prog Ser 204: 225-242

McArdle BH, Anderson MJ (2001) Fitting multivariate models to community data: a comment on distance-based redundancy analysis. Ecology 82:290-297 
McIvor C, Rozas LP (1996) Direct nekton use of intertidal saltmarsh habitat and linkage with adjacent habitats: a review from the southeastern United States. In: Nordstrom KF, Roman CT (eds) Estuarine shores: evolution, environments and human alterations. Wiley \& Sons, New York, NY p 311-334

Middaugh DP (1981) Reproduction ecology and spawning periodicity of the Atlantic silverside, Menidia menidia (Pisces: Atherinidae). Copeia 1981:766-776

Middaugh DP, Takita T (1983) Tidal and diurnal spawning cues in the silverside, Menidia menidia. Environ Biol Fishes 8:97-104

Monteiro C, Lam Hoai T, Lasserre G (1987) Chronological assemblages of fishes in 2 stations of the Ria Formosa lagoon (Portugal). Oceanol Acta 10:359-371

Morton RM, Pollock BR, Beumer JP (1987) The occurrence and diet of fishes in tidal inlet to a saltmarsh in southern Moreton Bay, Queensland. Aust J Ecol 12:217-237

Orth RJ, Heck KL Jr., van Montfrans J (1984) Faunal communities in seagrass beds: a review of the influence of plant structure and prey characteristics on predator-prey relationships. Estuaries 7:339-350

Paterson AW, Whitfield AK (1996) The fishes associated with an intertidal salt marsh creek in Kariega Estuary, South Africa. Trans R Soc S Afr 51:195-218

Paterson AW, Whitfield AK (2000a) The ichthyofauna associated with an intertidal creek and adjacent eelgrass beds in the Kariega Estuary, South Africa. Environ Biol Fishes 58:145-156

Paterson AW, Whitfield AK (2000b) Do shallow-water habitats function as refugia for juvenile fishes? Estuar Coast Shelf Sci 51:359-364

> Paterson AW, Whitfield AK (2003) The fishes associated with three intertidal salt marsh creeks in a temperate southern African estuary. Wetlands Ecol Manage 11:305-315

Pollard DA (1984) A reviewed of ecological studies on seagrass-fish communities with particular reference to recent studies in Aust. Aquat Bot 18:3-42

Rakocinski CF, Baltz DM, Fleeger JW (1992) Correspondence between environmental gradients and the community structure of marsh-edge fishes in a Louisiana estuary. Mar Ecol Prog Ser 80:135-148

Ribeiro J, Bentes L, Coelho R, Gonçalves JMS, Lino PG, Monteiro P, Erzini K (2006) Seasonal, tidal and diurnal changes in fish assemblages in the Ria Formosa coastal lagoon (Portugal). Estuar Coast Shelf Sci 67:461-474

Ribeiro J, Bentes L, Coelho R, Gonçalves JMS, Lino PG, Monteiro P, Erzini K (2008) Long-term changes in fish communities of the Ria Formosa coastal lagoon (southern Portugal): comparison based on two studies made 20 years apart. Estuar Coast Shelf Sci 76:57-68

Rossi R (1986) Occurrence, abundance and growth of fish fry in Scardovari Bay, a nursery ground of the Po River delta (Italy). Arch Oceanogr Limnol 20:259-280

Rountree RA, Able KW (1992) Fauna of polyhaline subtidal marsh creeks in southern New Jersey: composition,

Editorial responsibility: Konstantinos Stergiou, Thessaloniki, Greece abundance and biomass. Estuaries 15:171-185

Rozas LP, Minello TJ (1998) Nekton use of salt marsh, seagrass, and nonvegetated habitats in a south Texas (USA) estuary. Bull Mar Sci 63:481-501

> Rozas LP, Zimmerman RJ (2000) Small-scale patterns of nekton use among marsh and adjacent shallow nonvegetated areas of the Galveston Bay Estuary, Texas (USA). Mar Ecol Prog Ser 193:217-239

Salgado JP, Costa MJ, Cabral HN, Deegan L (2004a) Comparisons of the fish assemblages in tidal salt marsh creeks and in adjoining mudflat areas in the Tejo estuary (Portugal). Cah Biol Mar 45:213-224

Salgado JP, Cabral HN, Costa MJ, Deegan L (2004b) Nekton use of salt marsh creeks in the upper Tejo estuary. Estuaries 27:818-825

SAS Institute (1988) SAS/STAT users Guide, release 6.03 edition. SAS Institute, Cary, NC

Shannon CE, Wiener W (1949) The mathematical theory of communication. University of Illinois Press, Urbana

Shenker JM, Dean JM (1979) The utilisation of an intertidal salt marsh creek by larval and juvenile fishes: abundance, diversity and temporal variation. Estuaries 2: 154-163

Smith SM, Hoff JG, O'Neil SP, Weinstein MP (1984) Community and trophic organisation of nekton utilising shallow marsh habitats, York River, Virginia. Fish Bull US 82: 455-467

> Sogard SM, Able KW (1991) A comparison of eelgrass, sea lettuce macroalgae, and marsh creeks as habitats for epibenthic fishes and decapods. Estuar Coast Shelf Sci 33:501-519

> Thomas BE, Connolly RM (2001) Fish use of subtropical saltmarshes in Queensland, Australia: relationships with vegetation, water depth and distance onto the marsh. Mar Ecol Prog Ser 209:275-288

Underwood AJ (1997) Experiments in ecology. The logical design and interpretation using analysis of variance. Cambridge University Press, Cambridge

Veiga P, Vieira L, Bexiga C, Sá R, Erzini K (2006) Structure and temporal variations of fish assemblages of the Castro Marim salt marsh, southern Portugal. Estuar Coast Shelf Sci 70:27-38

Weinstein MP (1979) Shallow marsh habitats as primary nurseries for fishes and shellfish, Cape Fear River, North Carolina. Fish Bull US 77:339-357

- Weinstein MP, Brooks HA (1983) Comparative ecology of nekton residing in a tidal creek and adjacent seagrass meadow: community composition and structure. Mar Ecol Prog Ser 12:15-27

> Weinstein MP, Weiss SL, Walters MF (1980) Multiple determinants of community structure in shallow marsh habitats, Cape Fear estuary, North Carolina, USA. Mar Biol 58:227-243

Whitfield AK (1988) The Swartvlei estuary fish community and the influence of food availability on resource utilization. Estuaries 11:160-170

Submitted: June 22, 2011; Accepted: October 19, 2011 Proofs received from author(s): January 18, 2012 